\title{
PARATHYROID HORMONE IN THE BLOOD OF PREGNANT WOMEN 1
}

\author{
By BENGT HAMILTON, LAURA DASEF, WALTER J. HIGHMAN, JR., AND \\ CHARLES SCHWARTZ \\ (From the Department of Obstetrics and Gynecology and the Department of Pediatrics, \\ University of Chicago, Chicago)
}

(Received for publication February 10, 1936)

Histological changes indicative of hyperactivity have been found in the parathyroid glands of pregnant women by several investigators $(1,2)$. It has further been shown $(3,4)$ that it is possible to extract from large amounts of blood of pregnant women a substance that behaves pharmacologically like parathyroid hormone; this substance was not found in the blood of non-pregnant women.

Some years ago we described a method, since somewhat modified, for the demonstration of small amounts of parathyroid hormone $(5,6)$, and it was found that the hyperparathyroidism of rickets could be demonstrated by the use of only $30 \mathrm{cc}$, or less, of the blood from rachitic rabbits (7). The method is, briefly, as follows. If calcium chloride is administered at regular intervals to rabbits by stomach tube, one finds, generally, that the rise in serum calcium becomes less and less after each administration. If, however, parathyroid hormone, or any substance containing it in sufficient amounts, is given to the animals intramuscularly before the experiments, the rise in blood calcium is quite marked also after the later administrations of calcium chloride by mouth. The figure by which the results are judged is the difference between the rabbit's blood calcium before the experiment and the highest value obtained three or five hours later. This method has been successfully used not only by us but also by Shelling and Remsen (8) and by Dyer (9). The latter author points out that the rise obtained is not proportional, in the individual case, to the amounts of parathyroid hormone injected. We agree with Dyer on this point; just as in the dog, the amount of reaction varies in different rabbits, and we do not think that accurate quantitative information can be obtained from single experiments. Quantitative differences can, we believe,

\footnotetext{
${ }^{1}$ Read before the Fiftieth Session of the Association of American Physicians at Atlantic City, May 1935.
}

be studied only by using sufficiently large groups.

Our results are summarized in Table I. The first column gives the rise of the rabbit's serum

TABLE I

Rise in the serum calcium of rabbits after the injection of blood from 30 normal, non-pregnant, 74 pregnant and 11 lactating women

\begin{tabular}{|c|c|c|c|c|c|c|}
\hline \multirow[b]{2}{*}{ Rise } & \multirow{2}{*}{$\begin{array}{c}\text { Nor- } \\
\text { mal }\end{array}$} & \multicolumn{4}{|c|}{ Pregnant } & \multirow{2}{*}{\begin{tabular}{|c}
$\begin{array}{c}\text { Lac- } \\
\text { tating }\end{array}$ \\
6 \\
$\begin{array}{c}6 \\
\text { to } \\
\text { weeks }\end{array}$ \\
\end{tabular}} \\
\hline & & $\begin{array}{c}\text { Less } \\
\text { than } \\
15 \\
\text { weeks }\end{array}$ & $\begin{array}{c}15 \\
\text { to } \\
24 \\
\text { weeks }\end{array}$ & \begin{tabular}{|c}
25 \\
to \\
34 \\
weeks
\end{tabular} & $\begin{array}{l}\text { More } \\
\text { than } \\
34 \\
\text { weeks }\end{array}$ & \\
\hline $\begin{array}{c}m M . \text { per liter } \\
0.00 \text { to } 0.09{ }^{*} \ldots \\
0.10 \text { to } 0.19 \ldots \ldots \\
0.20 \text { to } 0.29 \ldots \ldots \\
0.30 \text { to } 0.39 \ldots \ldots \\
0.40 \text { to } 0.49 \ldots \ldots \\
0.50 \text { to } 0.59 \ldots \ldots \\
0.60 \text { to } 0.69 \ldots \ldots\end{array}$ & $\begin{array}{r}27 \\
1 \\
2\end{array}$ & $\begin{array}{l}8 \\
7 \\
1\end{array}$ & $\begin{array}{l}6 \\
2 \\
3 \\
6 \\
2 \\
4 \\
5\end{array}$ & $\begin{array}{l}1 \\
3 \\
2 \\
1 \\
1 \\
6 \\
3\end{array}$ & $\begin{array}{l}7 \\
3 \\
2 \\
1\end{array}$ & 10 \\
\hline
\end{tabular}

* Cases with a decrease instead of a rise are included in this group.

calcium after the injection of woman's blood; the following columns give the number of cases showing the rise of calcium indicated by the first column. It may be seen that of the 30 non-pregnant cases 27 gave either a decrease, no rise or a very small rise in the rabbit's serum calcium. Quite similar results were obtained with the blood from women pregnant less than 15 weeks; the figures fall within the limits obtained in non-pregnant women. In the next two groups, however, (15 to 24 weeks and 25 to 34 weeks) we find a considerable number of cases where abnormally great rises were obtained, indicating that during this period of pregnancy an increase in the amount of parathyroid hormone present in the blood is rather common. Towards the end of pregnancy, however (sixth column), these cases are much less common, only 3 out of 13 cases showing an abnormal rise, and still more rare does such a re- 
sponse seem to be during the period of lactation included in our study.

We have also calculated the mean rise for each of the four periods of pregnancy listed in Table I. were the direct cause of the effect observed on the blood calcium of the rabbit, some of these hormones were injected into rabbits, following the same technique as in the tests for parathyroid

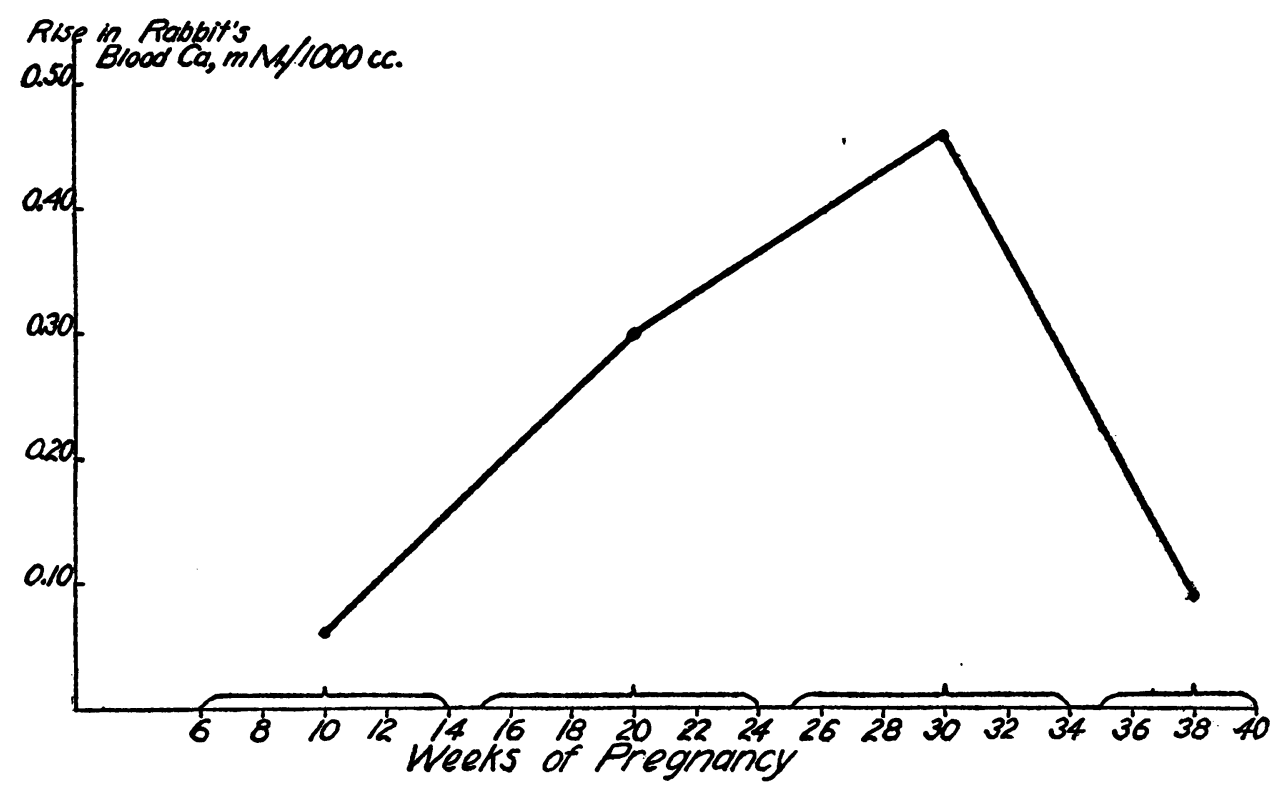

Fig. 1. Average Rise in the Serum Calcium of Rabaits after the Injection of Blood from Pregnant Women (74 Cases).

A curve based on these means is shown in Figure 1 , and as we have convinced ourselves that the difference between each two succeeding points on this curve is statistically significant, we think that we are justified in concluding that this curve gives an approximate idea of the degree of hyperparathyroidism during different periods of pregnancy. It must be pointed out, however, that according to Hoffmann $(3,4)$ the most potent extract can be prepared from the blood of women in the tenth month of pregnancy. Our findings indicate (Table I, Figure 1) that the blood is richer in parathyroid hormone during the seventh month than at any other time, and that in the tenth month the hormone content has usually returned to normal amounts. In order to study this matter further, we have made some observations on a pregnant dog (Figure 2); in this dog, just as in the women, we found the hormone content of the blood returning to normal just before delivery.

In order to exclude the possibility that other hormones which may be present in the blood of pregnant women in more than normal amounts hormone. The results are tabulated in Table II, and it may be seen that none of the substances tested effected a rise in blood calcium at all comparable with that obtained by the injection of

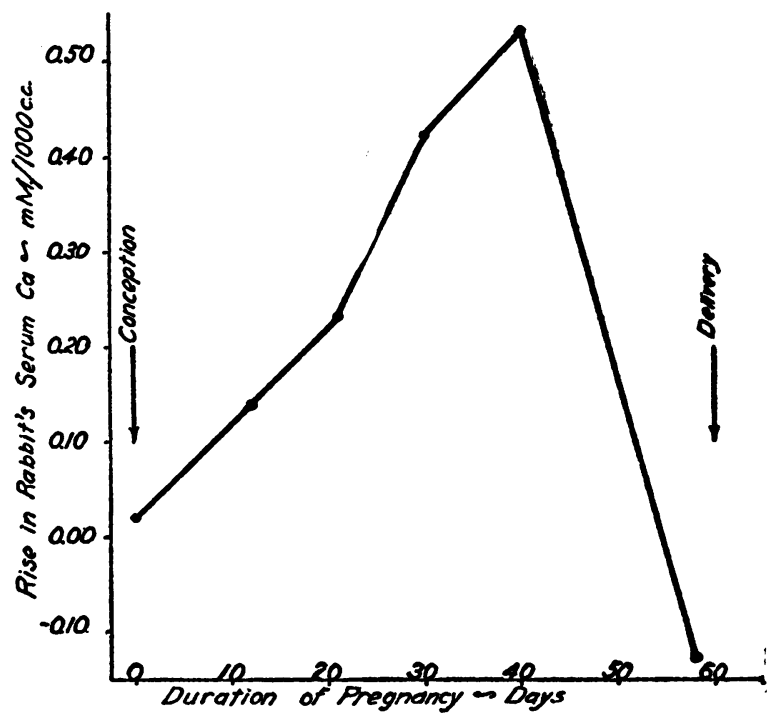

Fig. 2. Rise in the Serum Calcium of Rabbits after the Injection of Blood from a Pregnant Dog. 
TABLE II

Rise in the serum calcium of rabbits after injection of various hormones

\begin{tabular}{|c|c|c|}
\hline Hormone & Amount injected & $\begin{array}{l}\text { Rise in rabbit's } \\
\text { blood calcium * }\end{array}$ \\
\hline $\begin{array}{l}\text { Theelin } \\
\text { (Parke and Davis) } \\
\text { Water solution } \\
\text { Theelin, in oil }\end{array}$ & $\begin{array}{l}0.5 \mathrm{cc} . \\
1.0 \mathrm{cc} . \\
1.5 \mathrm{cc} . \\
2.0 \mathrm{cc} . \\
1.0 \mathrm{cc} .\end{array}$ & $\begin{array}{c}\text { mM. per liter } \\
0.03 \\
0.04 \\
0.00 \\
0.06 \\
0.08\end{array}$ \\
\hline Prolan & $\begin{array}{l}\text { Extract from } 83 \mathrm{cc} . \\
\text { of urine } \\
\text { Extract from } 83 \mathrm{cc} \text {. } \\
\text { of urine } \\
\text { Extract from } 83 \mathrm{cc} . \\
\text { of urine }\end{array}$ & $\begin{array}{l}0.20 \\
0.05 \\
0.04\end{array}$ \\
\hline Thyroxin & $2 \mathrm{mgm}$. & $\begin{array}{l}0.00 \\
0.10\end{array}$ \\
\hline Adrenalin & $\begin{array}{l}0.04 \mathrm{mgm} \text {. per kgm. } \\
0.03 \mathrm{mgm} \text {. per kgm. } \\
0.04 \mathrm{mgm} \text {. per kgm. }\end{array}$ & $\begin{array}{r}-0.02 \\
0.27 \\
-0.08\end{array}$ \\
\hline
\end{tabular}

* When blood from women, pregnant 25 to 34 weeks was injected, the average rise was $0.46 \mathrm{mM}$. per liter (Figure 1); individual cases caused a rise to 0.60 to 0.69 mM. per liter (Table I).

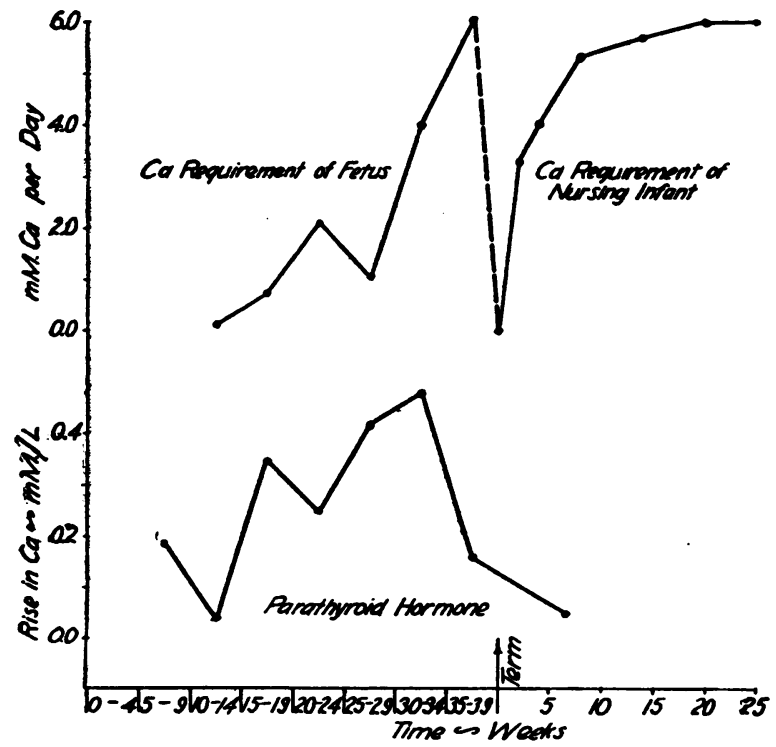

Fig. 3. Comparison between Calcium Requirements of Fetus and the Parathyroid Hormone Content in the Blood of Pregnant Women.

The calcium requirements of the fetus are calculated from the figures given by Iob and Swanson (20), those of the nursing infant from average figures given in current handbooks. The average hormone content in the blood has here been calculated for periods half as short as those used in Table I and Figure 1. blood from pregnant women. However, we do not know whether any of these substances might, indirectly, by stimulating the parathyroid glands, have been responsible for the increased amounts of parathyroid hormone found in the blood.

\section{DISCUSSION}

In Figure 3 a comparison has been made between the calcium requirements of the fetus and the nursing infant, and the parathyroid hormone content of the blood of pregnant and lactating women. At first these curves show a rough parallelism, on the whole they are both rising until the 34th week of pregnancy. At that time, however, they diverge sharply, the hormone content returning to normal while the calcium requirements show a marked increase.

It is possible that the parallelism of these two curves during the greater part of pregnancy indicates a causal relationship; that the increasing demands of the growing fetus with respect to calcium furnish a stimulus to the parathyroid glands. If that is true, we would have to assume that during the last weeks of pregnancy and during lactation, this stimulus, for some unknown reason, ceases to be effective, and it is interesting to note that during this period there seems to be some tendency towards true tetany with lowering of the serum calcium (10 to 19 ). It is customary to ascribe such a tendency to less than normal activity of the parathyroid glands. Our studies do not give any information as to whether the parathyroid hormone content in the blood is normal or less than normal. It is probable, however, that in the presence of an abnormal calcium metabolism (as in rickets) or unusual demands on the calcium metabolism (as in pregnancy) an insufficient amount of hyperactivity might also result in tetany.

In conditions such as pregnancy or rickets the hyperactivity of the parathyroid glands is accompanied by a serum calcium that, generally, is normal but occasionally shows a tendency towards low values. We believe that the hyperparathyroidism in these cases is of a different significance than in osteitis fibrosa cystica, where the serum calcium is high. Perhaps it would be a useful concept if we divided the various conditions in which hyperparathyroidism is found into two 
groups: primary, with high serum calcium, and secondary, where the serum calcium is normal or low.

\section{SUM MARY}

The content of parathyroid hormone in the blood was frequently found to be higher than normal from the fifteenth to the thirty-fifth week of pregnancy.

\section{BIBLIOGRAPHY}

1. Ritter, C., Uber Epithelkörperchenbefunde bei Rachitis und anderen Knochenerkrankungen. Frankfurt. Ztschr. f. Path., 1920, 24, 137.

2. Seitz, L., Eklampsie und parathyreoidea. Arch. f. Gynäk., 1909, 89, 53.

3. Hoffmann, F., Uber die Darstellung und den Nachweis des Nebenschilddrüsenhormons im Schwangerenblut. Arch. f. Gynäk., 1933, 153, 181.

4. Hoffmann, F., and Rhoden, E., Untersuchungen über die Wirkung des Nebenschilddrüsenhormons aus Schwangerenblut. Arch. f. Gynäk., 1934, 156, 459.

5. Hamilton, B., and Schwartz, C., A method for the determination of small amounts of parathyroid hormone. J. Pharmacol. and Exper. Therap., 1932, 46, 285.

6. Hamilton, B., and Highman, W. J., Jr., A test for abnormally large amounts of parathyroid hormone in the blood. J. Clin. Invest., 1936, 15, 99.

7. Hamilton, B., and Schwartz, C., Rickets and hyperparathyroidism. Am. J. Dis. Child., 1933, 46, 775.

8. Shelling, D., and Remsen, D., Renal rickets. Report of a case showing four enlarged parathyroids and evidence of parathyroid hypersecretion. Bull. Johns Hopkins Hosp., 1935, 57, 158.

9. Dyer, F. J., The use of rabbits in the standardisation of parathyroid hormone. Quart. J. Pharm. and Pharmacol., 1935, 8, 197.

10. King, G., A case of tetany complicating pregnancy toxaemia. J. Obst, and Gynaec. Brit. Emp., 1930, 37, 76.

11. Brindeau, A., Un cas de tétanie gravidique. Bull. Soc. d'obst. et de gynecol., 1933, 22, 599.

12. Vermelin, H., Tétanie et accouchement. Bull. Soc. d'obst. et de gynéc., 1933, 22, 305.

13. McGill, J. W., Maternal tetany. Wisconsin M. J., 1930, 29, 370.

14. Seitz, L., Eklampsie und Parathyreoidea. Verhandl. d. deutsch Gesellsch. f. Gynäk., 1909, 13, 357.

15. McCarrison, R., Endemic tetany in the Gilgit valley. Lancet, 1911, 1, 1575.

16. Lisser, H., Smith, R. K., and Shepardson, H. C., A case of maternal tetany relieved by parathyroid extract-Collip. J. A. M. A., 1927, 88, 461.

17. Vassale, G., Sur les effets de l'extirpation des glandes parathyreoidiennes. Arch. ital. de biol., 1896, 26, 61.

18. Adler, L., and Thaler, H., Experimentelle und klinische Studien über die Graviditätstetanie. Ztschr. f. Geburtsh. u. Gynäk., 1908, 62, 194.

19. Spiegler, R., and Schol, W., Die galvanische NervenMuskelerregbarkeit in der Schwangerschaft und bei Toxikosen. Arch. f. Gynäk., 1930, 141, 651.

20. Iob, V., and Swanson, W. W., Mineral growth of the human fetus. Am. J. Dis. Child., 1934, 47, 302. 